DOI https://doi.org/10.18551/rjoas.2018-08.09

\title{
ANALYSIS OF E-TAX IMPLEMENTATION IN MALANG CITY OF INDONESIA: A REVIEW BASED ON THE TEN GUIDING PRINCIPLES OF GOOD TAX POLICY
}

\author{
Anggoro Damas Dwi \\ Faculty of Administrative Science, University of Brawijaya, Indonesia \\ E-mail: damasdwia@gmail.com
}

\begin{abstract}
Self assessment system demands the active role of the taxpayer in fulfilling his tax obligations. One of the means is through the implementation of e-tax in Malang City, Indonesia. E-tax is an online tax system that aims to reduce potential tax leak by connecting all transactions from customers with servers. The purpose of this study is to analyze the implementation of e-tax in Malang city based on ten guiding principles of good tax policy. This study uses a qualitative approach. Data collection uses literature study (secondary data). The results of this study explain that in genera, e-tax implementation in Malang City has fulfilled the principle of a good tax policy that prioritizes the principle of acceptance and provide simplicity and convenience for the taxpayer in the fulfillment of tax obligations. However in terms of the principle of fairness, it has not fulfilled the principle yet because there is still no optimal data collection of taxpayers in some tax sectors.
\end{abstract}

\section{KEY WORDS}

Self assessment system, tax policy principle, e-tax.

Local taxes have function as a source of revenue to meet the financing of regional development that are useful for the benefit of the community. Local taxes also function as one of the areas that have the biggest contribution in regional revenue (figure 1). Based on data from the Regional Tax Service Agency (BP2D) of Malang City, Locally-Generated Revenue from local tax sector has increased in each year, as shown in the following table:

Table 1 - Percentage of Locally-Generated Revenue to Total Revenue of Malang City, 2012-2016

\begin{tabular}{|c|c|c|c|c|}
\hline \multirow{2}{*}{ Year } & \multicolumn{4}{|c|}{ Locally-Generated Revenue (LGR) in Billion } \\
\cline { 2 - 5 } & Local Tax & Local Retribution & Management of Regional Asset Results & Other legitimate LGR \\
\hline 2012 & 125 & 33 & 20 & 20 \\
\hline 2013 & 210 & 38 & 21 & 28 \\
\hline 2014 & 260 & 40 & 11 & 35 \\
\hline 2015 & 272 & 40 & 15 & 22 \\
\hline 2016 & 301 & 48 & 15 & 36 \\
\hline
\end{tabular}

Source: BP2D, 2017.

The growth of local tax revenues from 2012 to 2016 continued to increase. It was not separated from active role of the community in assisting regional financing by making tax payments. Regional government of Malang City continues to increase local tax revenue by utilizing the development and application of information technology. Utilization of information technology provides ease of administration. One of the strategies undertaken by Government of Malang City, specifically, Regional Tax Service Agency of Malang or BP2D is the application of online tax or electronic tax (e-tax).

Implementation of e-tax in Malang city has existed since 2013. Malang became the second city in Indonesia after DKI Jakarta which has applied e-tax in the fulfillment of tax obligation. Implementation of e-tax is an effort from the tax authorities to provide convenience to taxpayers by utilizing technological progress so as to encourage the creation of voluntary compliance and can increase tax revenue of Malang City.

Implementation of e-tax in Malang is still limited to 3 tax sectors, namely: hotel tax, restaurant tax, and parking tax. Implementation of e-tax is a strategy of BP2D to reduce the 
level of revenue leak for the three types of taxes and facilitate the implementation of the self assessment system.

Based on the above description, it is interesting to see the implementation of e-tax from a different perspective rather than only focusing on revenue. The formulation of the problem in this research is How is the Analysis of E-Tax implementation in Malang City based on 10 Guiding Principles of Good Tax Policy according to AICPA?

\section{LITERATURE REVIEW}

Local Tax. Davey (1988) argued that local taxes can be interpreted as:

- Taxes levied by Regional Government with the regulation of the region itself;

- Taxes levied under national regulations but the determination of tariffs is done by Regional Government;

- Taxes determined and/or levied by Regional Government;

- Taxes levied and administered by the Central Government but the proceeds of collection shall be granted to, be distributed with, or incurred additional levies by Regional Government.

Tax Collection Principles. The implementation of positive taxation policy is a process of selecting tax treatments from various alternatives available, in order to achieve the intended target from the tax system to be prepared. These alternatives are selected while taking into consideration the specified taxation principles.

There are basically three tax collection principles which are applied in every tax system, namely (Mansyuri, 1996):

- Revenue productivity. This principle uses taxes as a community fundraiser;

- Equity. This principle makes the basis of fairness in tax collection;

- Ease of administration. This principle states that taxation is done based on legal certainty, taxpayer convenience, and is efficient. It should also be supported by easy-to-understand regulation and without causing distortion.

In the concept of ease of administration, wherever it is done, tax collection should consider the principles underlying a tax collection system. The concept of ease of administration has elements such as (Haula and Irianto, 2012):

- The principle of certainty. The certainty principle states that there must be certainty, both for tax officials and all taxpayers and the whole society. The principle of certainty includes, among other things, the certainty of who should be taxed, what is used as tax object, and the amount of tax to be paid and how the amount of indebted tax should be paid.

- The principle of convenience. This principle states that the time of tax payment should be possible at a pleasant time/facilitate the taxpayer, for example, when receiving a salary or other income such as receiving a gift or deposit interest

- The principle of efficiency. This principle states that from the taxpayer side, the tax collection system is said to be efficient if the cost that must be issued by the taxpayer to meet the tax obligations can be as minimum as possible. In other words, tax collection is said to be efficient if its cost of compliance is low.

- The principle of simplicity. Tax regulations should be simple to be more certain, clear and easy to understand by the taxpayer.

Meanwhile, the American Institute of Certified Public Accountants (AICPA) states there are Ten Guiding Principles of Good Tax Policy. The sequence number of principles in these ten statements is only as a reference and should not be taken as an indication of the order of importance of these principles (AICPA, 2001):

- Equity and Fairness. This principle states that the same situation of the taxpayer should be subject to the same tax. This same tax principle is often explained in terms of fairness.

- Certainty. The tax regulation should determine when taxes are to be paid, how taxes should be paid, and how much to pay will be determined. A person's tax obligations 
must be certain and not ambiguous. This certainty is important for the tax system as it helps to improve tax compliance and to improve compliance with the system. Certainty generally comes from clear laws and proper and understandable administrative guidelines for taxpayers.

- Convenience of Payment. This principle states that taxes are levied at the right time and in the most probable way to be collected for the convenience of the taxpayer. Payment convenience is important in helping to ensure taxpayer compliance with the tax system. Sommerfeld links the convenience principle with administration simplicity.

- Economy in Collection. The cost of collecting taxes should be as minimal as possible for the government and taxpayers. These costs include administrative costs to governments that are affected by the number of tax officials (fiscal authorities) required to manage taxes. Compliance costs that are also incurred by taxpayers need to be considered. This principle is also closely related to the principle of simplicity. The more complex the tax, the greater the cost for the government to manage and the greater the compliance cost for the taxpayer to determine his tax liability and report it. From the fiscal authorities' side, the more appropriate term used to measure efficiency is administrative cost (Cedric, 1989). "The term 'administrative cost' can be used for the public sector costs of running the tax system - principally the costs incurred by the revenue department, whilst 'operating costs' is a convenient term to embrace the total costs of running a tax or the tax system, i.e. administrative and compliance costs combined." As Cedric puts it, Administrative costs are the costs the government must spend to run the tax administration system. For example not only the cost of the salaries of tax officials, but also other operational costs, the costs of extension/socialization of taxes and costs for law and justice enforcement (billing, checking, objections, appeals, etc.). Compliance costs incurred by taxpayers need to be considered. Costs of Collection is an administrative burden that must be borne by the taxpayer to carry out his tax obligations. According to Cedric Sanford in Rosdiana, the costs or expenses can not only be measured by tangible value, but also costs that can not be measured by the value of money (intangiable) to be incurred/borne by the taxpayer in connection with the implementation process of taxation obligations and rights. Such as Fiscal cost (honorarium, salary, consultant services, transportation), Time cost and Psychological costs. (Rosdiana and Irianto, 2012)

- Simplicity. The tax law should be simple so that taxpayers understand the rules and can comply with them properly and in a cost-effective manner. Simplicity in the tax system is important both to the taxpayer and to the people who manage the various types of taxes. Taxes should be simple enough so that the affected can understand the tax easily. A complicated rule causes errors and does not respect systems that can reduce compliance. Simplicity is important both to improve compliance processes and to enable taxpayers to better understand the tax consequences of each transaction.

- Neutrality. Taxes should be free of distortions, either distortions to consumption or distortions to production and other economic factors. This means that taxes should not affect the choice of people to consume and also do not affect the choice of producers to produce goods and services, and do not reduce the enthusiasm of people to work. Therefore, in determining the tariff, the authorities should not select tariffs included in the "prohibited area". Raising tax rates is not necessarily going to increase tax revenues, otherwise it might lead to lower the revenues. It's similar in providing tax incentives. The policy of providing tax incentives should ensure a level playing field that is "fair" so as not to cause entry barriers (Haula and Irianto, 2012).

- Economic Growth and Efficiency. The tax system should not hinder or reduce the productive capacity of the economy. The tax system should not prevent or impede national economic goals, such as economic growth, capital formation, and international competitiveness. The principle of economic growth and efficiency related to the principle of neutrality in the tax regulation can distort the behavior of the taxpayer which may impede economic efficiency. 
- Transparency and Visibility. The taxpayer must know about the existence of tax and how and when it is levied on the taxpayer. Visibility or clarity allows individuals and businesses to know the true cost of each transaction made. It also allows taxpayers to see their total tax liabilities. When the tax is not visible, taxpayers can easily evade or avoid the obligations of taxation. There will be a little awareness of taxpayers about how taxes affect themselves.

- Minimum Tax Gap. Taxes must be structured to minimize violations. A tax gap is the difference between indebted tax and tax paid voluntarily. The existence of a tax gap is due to various reasons, such as a deliberate error (non-filing, unreported earnings, exaggeration of deductions, deferral of transactions) and unintentional mistakes (mathematical errors and lack of understanding of rules).

- Appropriate Government Revenues. The tax system should allow the government to determine how much tax revenue might be collected and when the tax revenue is received by the government. The tax system must have some degree of predictability and reliability to allow the government to determine how much income taxes are likely to be collected and when the tax revenue is received by the government.

E-tax. E-tax is an online tax system that aims to reduce potential tax leaks. This system will connect all transactions from the customer with the server so that the taxpayer can not manipulate the indebted tax. (BP2D, 2017). Currently, there are 3 types of taxes that use etax system in Malang City, namely, hotel taxes, restaurant taxes, and parking taxes.

\section{METHODS OF RESEARCH}

This study uses a qualitative approach which is a process of understanding of a social problem proposed to analyze the implementation of e-tax in Malang based on 10 Guiding Principles of Good Tax Policy according to AICPA. Data collection is done by using secondary data sourced from books, research reports, and other references such as data from websites/internet that can be accounted for.

\section{RESULTS OF STUDY}

Implementation of online tax is applied for 3 types of local taxes in Malang City, namely, hotel taxes, restaurant taxes, and parking taxes. E-tax is an online tax system that aims to reduce potential tax leaks. this system will connect all transactions from the customer with the server so that the taxpayer can not manipulate indebted tax.

Implementation of e-tax in Malang City can provide certainty to the taxpayer about the tax object of the restaurant tax and non taxable objects. Objects of restaurant tax include restaurants, cafeterias, canteen, stalls, depots, bars, pujasera, bakeries, catering services or other similar business activities, while those excluding restaurant tax objects are services provided by restaurants with the highest sale value of Rp. 5,000,000.00 per month. In addition, the amount of tax that must be paid by the taxpayer also provides certainty with the existence of a case management system (CMS). The tax calculation contained in the CMS system has been adjusted to the regional regulation, namely Regulation No. 2 of 2015 on amendments to regional regulation No. 16 of 2010 on local taxes. Examples of restaurant tax that will be calculated is that the tax to be paid is $10 \%$ of turnover. The entertainment tax rate is based on the object. The parking tax rate is $20 \%$. On this basis, the implementation of etax by using CMS can provide clarity of regulations so that there is no double interpretation and has fulfilled the principle of certainty.

Based on the principle of economy in collection, the implementation of e-tax in Malang City facilitates taxpayer in payments and also facilitates tax officers in tax collection because the CMS system can calculate their own tax amount to be paid. This can reduce administrative costs in tax management by taxpayers. On this basis, the implementation of etax can be said to have fulfilled this principle.

Based on the principle of simplicity, the implementation of e-tax meets the principle of simplicity because of the facilities that have been provided such as case management 
system. The program will self-assess the tax amount to be paid by the taxpayer. The implementation of e-tax also facilitates taxpayers in payment because Malang City has cooperated with BRI Malang City, so that at the end of month, tax payments will automatically transferred into BP2D's bank account. In addition, the taxpayer does not need to attach the bill again in tax reporting. Ease of payment and reporting is essential to improve taxpayer compliance.

Based on the principle of transparency, with the implementation of e-tax system in Malang City, all transactions will be recorded properly and detected directly into the server and can be monitored in real time. Transparency will cover or at least reduce the potential for tax leakage. In addition, transparency can increase public trust that paid taxes are automatically monitored by the tax authority.

Under the minimum tax GAP, the tax should be structured to minimize violations. A tax gap is the difference between the indebted tax and the tax paid voluntarily. With the e-tax, the amount of indebted tax already can be known by a system called CMS. With this system, taxpayers will be easier in determining how much tax to be paid so as to avoid the difference between taxpayers and fiscal authorities. On this basis, the implementation of e-tax meets the principle of minimum tax GAP.

Under the principle of Convenience of Payment, payment convenience is important in helping to ensure taxpayer compliance. Malang City has cooperated with Bank Rakyat Indonesia so that tax payment can be done through e-banking or transfer that will automatically be transferred into BP2D's bank account. This provides convenience to the taxpayer without the need to come directly to the bank to make payments.

The principle of neutrality mentions that the effect of the tax law on the taxpayer's decision to execute a particular transaction or to engage in a transaction should be minimized. That is, taxpayers should not be overly encouraged or restricted from engaging in certain activities or certain transactions because the main purpose of taxes is to increase revenue, for governmental activities, not to influence business and personal decisions. Implementation of e-tax has fulfilled the principle of neutrality because it does not interfere with business decisions of a person.

The principle of Economic Growth and Efficiency states that the tax system should not inhibit or reduce the productive capacity of the economy. So far, the implementation of e-tax does not disrupt the economy. Chairman of Indonesian Association of Coffee and Restaurant Entrepreneurs (Apkrindo) of Malang Branch explained that the implementation of e-tax is very helpful, especially in terms of ease and transparency (BP2D, 2017).

Tax collection is said to be efficient if the cost of tax collection, in this case, the cost of taxpayer supervision is less than the amount of tax collected. The implementation of e-tax can increase efficiency because the cost of collection can be reduced to a minimum. The collection costs, also includes the cost of supervision, become low because the tax officer will be able to easily view the records of each taxpayer from this online system. In addition, the implementation of e-tax can reduce the interaction between fiscal authorities and taxpayers so as to reduce the burden of time and the number of field officers to conduct supervision. Supervision before the existence of e-tax was done through the calculation of taxpayer bill and inputed the data into the computer of tax service agency. Supervision was also done by cash opname that took a long time, supervision by way of silent operation that was performed by acting as the customer to ensure the condition of the taxpayer. The implementation of e-tax can improve efficiency in terms of time and cost. While from the taxpayer side, the implementation of e-tax also facilitates the taxpayer because they no longer need to pay taxes to the bank because it uses autodebet system. Based on this basis, the implementation of e-tax of Malang City can be said to fulfill the principle of economic growth and efficiency.

Appropriate Goverment Revenues, the tax system should allow the government to determine how much tax revenue might be collected and when the tax revenue is received by the government. The tax system should have some degree of predictability and reliability to allow the government to determine how much income of taxes are likely to be collected and when the tax revenue is received by the government. This is particularly important for 
regional government, most of whom can operate due to a balanced budget. With the e-tax, tax revenues in 3 sectors, namely, restaurant taxes, hotel taxes and parking taxes will be more secure because the transactions between taxpayers and customers are detected properly and it is directly connected to the server. Taxpayers can not manipulate the taxes to be paid so that taxes can be collected more optimally. Based on this, the implementation of e-tax has supported the government in terms of securing revenue in the three tax sectors.

Based on equity and fairness, the same situation of the taxpayer shall be subject to the same tax. This same tax principle is often explained in terms of fairness. In the case of applying e-tax, it can be said to fulfill the principle of fairness if all objects are subject to the same tax and there must be e-tax equalization for all three types of taxes. Constraints that occur at this time is: there is no optimal data collection of taxpayers, such as the object of restaurant tax in the form of catering business and bakery business, and there is no optimal data collection of hotel taxes in the form of boarding house taxes (BP2D, 2017). Business networking must be continuously carried out to meet the principles of fairness. On this basis, the principle of fairness in terms of even distribution of tax objects by using e-tax is still not fulfilled.

\section{CONCLUSION}

Based on the discussion on the implementation of e-tax in Malang city, it can be concluded that the application of e-tax can be analyzed based on ten guiding principles of good tax policy. The first analysis is in the principle of certainty. It can be concluded that the existence of e-tax for the three types of taxes can provide certainty and clarity for the taxpayer in the fulfillment of tax obligations. The second analysis is in the principle of economy in collection. It can be concluded that the ease provided by e-tax has fulfilled this principle. The third analysis is in the principle of simplicity. It can be concluded that the implementation of e-tax has fulfilled the principle of simplicity both for ease of payment and reporting. The fourth analysis is in the principle of transparency. It can be concluded that the implementation of e-tax has met the principle of transparency. The fifth analysis is in the principle of minimum tax gap, the implementation of e-tax has reduced the difference in turnover calculations between taxpayers and fiscal authorities. The sixth analysis is in the principle of Convenience of Payment. E-tax implementation can provide convenience in terms of payment and reporting. The seventh analysis is in the principle of neutrality. The application of e-tax has fulfilled this principle. The eighth analysis is in the principle of Economic Growth and Efficiency. E-Tax implementation can improve the efficiency of time, effort and cost. The ninth analysis in in the principle of Appropriate Government Revenues. E-tax implementation can reduce the potential of tax leakage so that the tax revenue of Malang city can increase in every year. The tenth analysis is in the principle of equity and fairness. The application of e-tax can not be said to fulfill this principle due to the uneven spread of business networking for these three tax objects.

\section{SUGGESTIONS}

There is a need for intensive taxpayer registration (extensification) on tax objects that have not been optimal, among others, the object of hotel taxes including boarding houses, data collection of restaurant tax objects such as catering and bakery.

There is a need for additional payment points in the public sphere so as to facilitate taxpayers in the fulfillment of tax obligations.

There is a need for expansion of cooperation with other banks for the tax banking program so as to facilitate the taxpayer in fulfilling his tax obligations.

\section{IMPLICATION AND LIMITATION}

This research attempts to analyze the implementation of e-tax in Malang City based on ten guiding principles of good tax policy. The results of this study are expected to provide 
evaluation of the implementation of e-tax in Malang. As an implication for the results of this study, the Government should seek equity of business networking with taxpayer data optimization or so-called extensification so that more and more taxpayers apply e-tax. Extensification is mainly done in boarding house business and catering \& bakery business. This can reduce the potential lost and ultimately can improve fairness and local tax revenues in Malang. Limitations in this study are analytical techniques used in this study only used secondary data so that the results of the study is in the form of general overview. Further research is expected to deepen the analysis by in-depth interviews by using the validity of data in the form of source triangulation.

\section{REFERENCES}

1. AICPA. (2001). Guiding Principles of Good Tax Policy: A Framework for Evaluating Tax Proposal, New York: American Institute of Certified Public Accountants 2001.

2. Badan Pelayanan Pajak Daerah Kota Malang. (2017). 40 Jurus BP2D Kota Malang. Malang: BP2D.

3. Bird, R., \& Francois, V. (2000). Desentralisasi Fiskal di Negara-Negara Berkembang. Jakarta: PT Gramedia Pustaka Utama.

4. Davey, K. J. (1988). Praktek-praktek Internasional dan relevansinya bagi dunia ketiga. Jakarta: UI Press

5. Devereux, M. P. (1996). Editor The Economics of Tax Policy. New York: Oxford University Press.

6. Law of The Republic Of Indonesia No. 28 Year 2009 on Regional Taxes and Retributions.

7. Mansyuri. (1996). Pajak Penghasilan Lanjutan. Jakarta: Ind Hill-Co.

8. Musgrave, R. A. \& Musgrave, P. B. (1993). Keuangan Negara dalam Teori dan Praktek $\left(5^{\text {th }} \mathrm{Ed}\right)$. Jakarta: Penerbit Erlangga.

9. Rosdiana, H. \& Tarigan, R. (2005). Perpajakan Teori dan Aplikasi. Jakarta: Raja Grafindo Persada.

10. Rosdiana, H. \& Irianto, E. S. (2012). Pengantar IImu Pajak, Kebijakan dan Implementasi di Indonesia. Jakarta: Raja Grafindo Persada.

11. Regional Regulation of Malang City No. 2 Year 2015 about the amendment of Regional Regulation No. 16 Year 2010 on Regional Taxes.

12. Regional Regulation of Malang City No. 16 Year 2010 on Regional Taxes. 